\title{
Mučeništvo kao jedno od obilježja prvih kršćanskih vremena
}

Božo GolužA

Sveučilište u Mostaru

Filozofski fakultet

E-pošta: bozo.goluza@ff.sum.ba
UDK: 272(091)

272-34

Stručni rad

Primljeno: 8. rujna 2018.

Prihvaćeno: 9. travnja 2019.

\section{Sažetak}

$\mathrm{Na}$ početku članka autor u najkraćim crtama govori o društveno-religioznim prilikama u kojima je rođena Kristova Crkva, jer je potrebno i Crkvu i njezine mučenike staviti u povijesni kontekst. Zatim se u radu razrađuje etimologija pojma, a onda i značenje riječi mučeništvo. Nakon ovoga iznesen je kratak pregled državnih progona Crkve. Ovdje je naglasak stavljen na one najžešće progone kako bi se oslikala najvažnija događanja iz prva tri stoljeća u kojima je Crkva proživljavala strahovite muke i patnje, ali to je i vrijeme u kojemu je krv mučenika postala sjeme novih mladica Kristove Crkve. Četvrti i najvažniji dio ovoga rada jest teologija mučeništva u ranom kršćanstvu. Ovdje su o mučeništvu iznijeta razna mišljenja kršćanskih otaca iz prvih stoljeća. Neki od tih crkvenih otaca i sami su postali mučenicima.

Ključne riječi: progon; mučenik; krštenje krvlju; vjera; spasenje.

* Autor je na ovu temu govorio na Međunarodnom znanstvenom skupu "Jubileji sv. Vlaha", održanom u Dubrovniku 21.-22. listopada 2016. 


\section{Društveno-religiozne okolnosti u kojima je rođena Crkva}

U židovskoj povijesti vjera je igrala najvažniju ulogu. Ovaj se izabrani Božji narod razlikovao od ostalih darom Objave i posebnim Božjim vodstvom. Najvažnije karakteristike te religije bili su monoteizam i iščekivanje obećanoga Mesije. Razne religiozno-društvene ustanove, od kojih su među važnijima bili proroci, čuvale su židovski narod od utjecaja poganstva. Dolazak Mesije bio je posebno aktualan u vrijeme Makabejaca, kada je kralj Sirije Antioh IV. Epifan (175. - 164. pr. Kr.) htio uništiti židovsku vjeru i nametnuti im pogansku vjeru i običaje. Velikom borbom i hrabrošću naroda i njegovih vođa taj plan poganskoga kralja nije uspio, te su Židovi zadobili političku neovisnost. Uvijek kada su dolazila teška vremena Židovi su se zbijali oko svetoga Zakona. S toga gledišta narodni vođe bili su farizeji, koji su u proučavanju i obdržavanju Zakona tražili svoj i narodni spas, odvajajući se od svega što nije židovsko. Uz njih važnu društvenu ulogu igrala je aristokratska partija saduceji, usmjereni racionalistički i epikurejski, bez vjere u uskrsnuće, a naginjali su helenističkoj kulturi. ${ }^{1}$

Rimski vojskovođa Pompej 63. godine pr. Kr. osvojio je Jeruzalem, ostavivši Židovima narodne vladare, ali zapravo Judeja je postala rimskim vazalom. Pod stranom okupacijom narodu je ostala jedina utjeha mesijanska ideja, koja je shvaćana uglavnom u političkom i nacionalnom smislu, jer se očekivao militaristički Mesija, spasitelj, izbavitelj od rimskoga ropstva i onaj koji će ponovo uspostaviti ovozemaljsku moć Izraela. Već duže vremena Židovi nisu živjeli samo u Palestini. Zbog asirske opasnosti u 8. i babilonske u 6. stoljeću pr. Kr. raspršili su se po susjednim zemljama. Židovi dijaspore (helenisti) bili su neke vrste zatvorena zajednica koja se premalo miješala s drugim narodima. Ipak, ne može se zanemariti ni utjecaj koji je na njih imao svijet u kojemu su živjeli. Usprkos njihovoj izoliranosti, Židovi dijaspore imali su jak religiozni utjecaj na poganski svijet. Grci i Rimljani ne samo da nisu poštovali Židove, nego su ih čak i prezirali, pa je zbog toga bio vrlo mali broj prozelita (obraćenika na židovsku vjeru) koji su prihvatili potpuno obdržavanje Zakona. Nasuprot tomu bio je velik broj onih koji su prihvatili monoteizam i određene židovske propise (subota, propisi o hrani itd.). Kršćanstvo

1 Karl Bihlmeyer - Hermann Tuechle, Storia della Chiesa, I., Morcelliana, Brescia, 1989., str. 56-58. 
je među ovima našlo mnoge pristaše, jer im je nudilo upravo ono što su željeli, a nije ih obvezivalo na suvišne židovske propise. ${ }^{2}$

$\mathrm{U}$ tim društveno-religioznim okolnostima rodio se Isus, a onda i njegova Crkva. Gospodin se obraća običnom puku, kojemu je i sam pripadao. Taj puk ni farizejima ni saducejima nije bio odveć važan, a Isus je došao svoje Evanđelje navijestiti upravo običnu čovjeku. Zaobilazeći društveno-religiozne predstavnike, štoviše, često ih je žestoko kritizirao, Isus je od početka svoga javnog djelovanja došao u sukob s etabliranim predstavnicima židovskoga naroda. ${ }^{3}$ Taj je sukob kulminirao nakon tri godine Isusova javnog djelovanja, te je završio njegovom mučeničkom smrću na križu. Svojom je mučeničkom smrću Isus dao primjer svojim učenicima kako istina ne trpi nikakav kompromis, pa i kada je u pitanju vlastiti život. Zato "mučenik odabire smrt kao najuzvišeniji čin svoje vjere, jer je to naučio od svoga Učitelja Isusa Krista".4

\section{Mučeništvo - pojam i značenje}

U novije vrijeme mnogo se raspravlja o podrijetlu i razvoju naziva mučenik, a često se koristi u potpuno krivom značenju, nazivajući nekoga mučenikom tko s vjerom nema nikakve veze. Grčki termin $\mu \alpha \dot{\alpha} \rho \tau v \varsigma$ ili $\mu \alpha \dot{\alpha} \rho \tau v \rho$, a latinski martyr (svjedok) najprije je korišten za apostole kao očevidce i svjedoke vjere u život i uskrsnuće Kristovo. Ubrzo su se tim pojmom počeli označavati oni koji su i po cijenu života ostajali vjerni Kristovoj radosnoj vijesti, da bi od polovice 2. stoljeća termin mučenik bio rezerviran samo za one koji su kršćanstvo posvjedočili svojom krvlju. Ostali svjedoci Istine nazivani su "ispovjedaocima" (confessores). ${ }^{5}$ Kršćansko mučeništvo temelji se na uzo-

2 Isto, str. 58-60.

3 Stipe Nimac, "Nastanak i razvoj prvih kršćanskih zajednica", u: Crkva u svijetu, 47, Split, 2/2012., str. 166.

4 Nikola Dogan, "Ludost križa. Teologija mučeništva", u: Crkva u svijetu, 41, Split, 4/2006., str. 444.

5 U prvim stoljećima kršćanstva "mučeništvo je glavni oblik svjedočenja kršćanske vjere u doba progona, a mučenik glavni kršćanski uzor. Ignacije Antiohijski (II. st.) dao je teološko obrazloženje mučeništva, a Polikarpovo mučeništvo (155) prvi je izvještaj ranokršćanskog mučeništva". "Mučeništvo", u: Opći religijski leksikon, Leksikografski zavod "Miroslav Krleža", Zagreb, 2002., str. 608; K. Bihlmeyer - H. Tuechle, nav. dj., str. 101-102; Nikola BižACA, "Zapažanja o teologiji mučeništva", u: Služba Božja, Split, 3/2009., str. 253. 
rima iz Staroga Zavjeta (Eleazar, Makabejci) i novozavjetnih Djela apostolskih (sv. Stjepan Prvomučenik, apostol Jakov st.). U prvoj Crkvi, "u skladu sa židovskom tradicijom, bilo je uobičajeno razlikovati sudbinu onih koji su umrli mučeničkom smrću od ostalih umrlih. Mučenicima se već pripisuje konačna slava". ${ }^{6}$

Štovanje mučenika počelo je u 2. st., a u 3. st. postaje općeprihvaćenim. Od 4. st. nad grobovima mučenika počele su se podizati crkve. U teološkoj tradiciji mučeništvo se smatralo djelom koje briše sve grijehe, a u nekrštenih "kršćana", katekumena, nadomještalo je krštenje vodom (baptismus sanguinis - krštenje krvlju). Već u prvim stoljećima kršćanstva nastali su prikazi o životu i smrti mučenika acta martyrum. ${ }^{7}$

Da bi netko dobio naslov kršćanskoga mučenika, potreban je jasan dokaz da je ubijen zbog mržnje prema vjeri (in odium fidei), a ne poradi nekoga drugog razloga koliko god bio plemenit, kao rodoljublje. Drugi važan uvjet da bi netko bio mučenik jest nepokolebljivo svjedočenje za Krista u trenutku pogubljenja. "Tko se opire borbom i umire s oružjem u rukama, nije mučenik u smislu Novoga Zavjeta." ${ }^{8}$ Kršćanski mučenik nije osoba koja prezire život kao dar Božji, što znači da se tu ne radi ni o kakvoj vrsti fanatizma, nego je to čovjek koji prihvaća kristovski način gledanja na svijet i stvarnost koja ga okružuje, te je za to svoje uvjerenje spreman podnijeti i nasilnu smrt. ${ }^{9}$ Znači, kršćansko obraćenje uključuje i spremnost na mučeništvo ukoliko do toga dođe, jer je ono pobjeda nad zlom, te zalog i jamstvo rasta Crkve. Mučeništvo je rođenje u Bogu i potpuna preobrazba u Isusu Kristu. "Kršćanin u Raspetome nalazi svoj identitet." ${ }^{10}$ Najizvrsnije svjedočanstvo za ove tvrdnje ostavio je u svojoj Poslanici Rimljanima sv. Ignacije Antiohijski, ${ }^{11}$ mučenik u rimskom Koloseju oko 107. godine.

6 Joseph Ratzinger (Benedikt XVI.), Eshatologija. Smrt i vječni život, Verbum, Split, 2016., str. 132.

7 "Mučenik", u: Hrvatska enciklopedija, 7, Zagreb, 2005., str. 504.

8 Joseph Ratzinger, Europa, Verbum, Split, 2005., str. 58.

9 N. BIžACA, nav. dj., str. 260.

10 N. Dogan, nav. dj., str. 445.

11 Paul Christophe, La Chiesa nella storia degli uomini, SEI, Torino, 1989., str. 30. 


\section{Državni progoni Crkve prvih stoljeća}

I danas se Rimsko Carstvo smatra nekom vrstom uzorne pravne države. Na svim pravnim fakultetima i u naše vrijeme studira se rimsko pravo. Kada su u pitanju progoni kršćana još uvijek nam je ostalo nejasno na kojoj je osnovi bilo utemeljeno kažnjavanje Kristovih sljedbenika, tj. ne možemo sa sigurnošću utvrditi pravnu podlogu progona. Naime, Tertulijan (oko 160. - oko 240.) prigovara rimskoj državi da progoni kršćane bez ikakve pravne osnove. Taj se prigovor ponajprije odnosio na naređenja koja je izdao car Trajan (98. - 117.) u svome reskriptu upućenu Pliniju Mlađemu po kojemu se kršćani trebaju kažnjavati kao kršćani (propter nomen ipsum). ${ }^{12}$ U Rimskome Carstvu sinkretizam, odnosno mnogoboštvo bilo je dominantno, a kult cara zauzimao je posebno mjesto i bio je obvezan za sve građane. U tim prilikama židovstvo je bilo jedina monoteistička religija, što će reći da je za Židove čašćenje rimskih bogova bilo idolatrija. Usprkos tomu, Carstvo je židovsku vjeru toleriralo, odnosno bila je religio licita (dopuštena religija). Ovdje se pojavljuje kontradiktorna situacija. Naime, iako je kršćanstvo smatrano "židovskom sektom", bilo je religio ilicita (zabranjena religija). ${ }^{13}$ Jasno, kršćani su odbijali prinositi žrtve poganskim bogovima i nisu prihvaćali kult cara, što je za rimsku religioznu državu bio ateizam. Bez obzira na sve ovo, i dalje nam ostaje nejasan odgovor na pitanje na kojim su pravnim osnovama počivali progoni kršćana. O kršćanskim progonima imamo malo sačuvanih dokumenata, kako carskih, tako i kršćanskih. Reskript cara Hadrijana (117. - 138.), oko 128. godine, u kojemu je naredio da svaka optužba protiv kršćana treba proći regularnu proceduru, također jasnije ne osvjetljava ovo pitanje. ${ }^{14}$

Apostol Pavao kaže da je propovijedanje Krista raspetoga i uskrsnuloga "Židovima sablazan, a poganima ludost" (1 Kor 1,23). Najveća oprječnost između rimskoga poganstva i kršćanstva bila je na području javnoga života. $U$ to vrijeme religija nije bila privatna stvar, nego je to bio državni interes, te su tako obitelj, društvo, kultura i cijeli društveni poredak bili usko vezani s mnogoboštvom.

12 August Franzen, Pregled povijesti Crkve, Kršćanska sadašnjost - Glas Koncila, Zagreb, 1970., str. 45.

13 Grgo Grbešić, "Progoni kršćana, napose u Dioklecijanovo doba", u: Diacovensia, XV., Đakovo, 1/2007., str. 22-23.

14 K. Bihlmeyer - H. Tuechle, nav. dj., str. 106-107. 
Rimsko je Carstvo podupiralo poganski kult, pa im nisu smetala ni božanstva naroda koje su pokorili. Štoviše, uvrštavali su ih među svoje bogove. Imajući ovo u vidu, sasvim je razumljivo zašto nisu prihvaćali sljedbenike monoteizma. Rimska je država u načelu bila tolerantna prema židovskom monoteizmu, jer je ta vjera bila ograničena na jedan narod, te je imala veoma malo obraćenika. Ali kršćanstvo je bilo sasvim drukčije od židovstva. To je sveopća vjera, koju su prihvaćali razni narodi, te je prijetila potiskivanjem poganskoga kulta i poganskih bogova. S obzirom na povezanost države i poganske religije u to vrijeme, mnogi su mislili da kršćanski monoteizam prijeti rušenjem samih temelja države. Ta se opasnost, po njihovu mišljenju, pokazala još većom kada kršćani nisu prihvaćali kult cara, koji se još prije bio raširio na Istoku, a u Neronovo i posebno Domicijanovo vrijeme i na Zapadu. Taj je kult bio vrhunac vjere starih Rimljana, a njime se mjerila građanska lojalnost, odanost državi i rodoljublje, pa je zbog toga onaj tko ga je odbijao mogao biti osuđen za veleizdaju. Upravo to se pripisivalo kršćanima. K tomu kršćani su odbijali prisustvovati raznim poganskim zabavama, a pojedinci poput Tertulijana i Origena odbijali su i vojničku službu. U svemu drugom kršćani su poštovali i priznavali državu. ${ }^{15}$ "Vjera Novoga Zavjeta ne poznaje revolucionara nego mučenika: mučenik priznaje autoritet države, poznaje, međutim, i njezine granice."16

Rimska poganska država u početku je bila tolerantna prema kršćanima. Doduše, car Klaudije (41. - 54.) oko 50. godine progonio je Židove u Rimu, koji su, prema optužbi, prouzročili mnoge nerede, te su tako na udar došli i kršćani židovskoga podrijetla, ali se to ne može smatrati progonom kršćana. ${ }^{17}$ Kako rekosmo, kršćanstvo je smatrano židovskom sektom. Usprkos tomu, ili možda upravo zbog toga, prema svjedočanstvima kršćanskih pisaca iz prva četiri stoljeća, Židovi su često na lokalnoj razini bili poticatelji progona protiv kršćana. ${ }^{18}$ Za ovu tvrdnju imamo potvrdu i u Euzebija Cezarejskoga kada opisuje mučeništvo Polikarpa iz Smirne: "Svjetina je iz radionica i kupališta donijela drva i piljevinu. U tome su, po svome običaju,

15 Isto, str. 96-98.

16 J. RAtZinger, Europa, str. 57.

17 K. Bihlmeyer - H. Tuechle, nav. dj., str. 103-105.

18 Joseph Lortz, Storia della Chiesa, I., Edizioni Paoline, Milano, 1987., str. 100, bilj. 26. 
na usluzi posebice bili Židovi."19 Polikarpovo mučeništvo opisano je kao liturgija. ${ }^{20}$

Možda se pitamo otkuda tolika silina progona koji su bili usmjereni protiv jedne miroljubive religije kakvo je bilo kršćanstvo? Komu i za što je to bilo potrebno? Rimsko je Carstvo udarilo na Kristove sljedbenike kada su vlastodršci u tome moćnom imperiju stekli uvjerenje da kršćani, javno priznajući jednoga Boga i Krista kao jedinoga Gospodina, niječu božanski karakter rimskih careva, te time izravno ugrožavaju "mir s bogovima" (pax deorum), koji je u rimskom pluralizmu bogova doživljavan kao najvažniji čimbenik stabilnosti toga imperija ${ }^{21}$ Religije "lokalnoga" karaktera, čak i bez obzira na monoteizam kakav je bio u židovstvu, u Carstvu nisu shvaćane kao nekakva veća prijetnja državnom poretku. S druge strane, kršćanstvo kao univerzalna religija, bez obzira što do sredine 3. stoljeća nije imalo neku veću društvenu važnost, prema mišljenju tadašnjih vlastodržaca, predstavljalo je prijetnju univerzalnom carstvu. ${ }^{22}$ Znači, monoteizam i univerzalnost, što automatski isključuje cara kao božanstvo, i to na području cijeloga Carstva, bili su glavnim razlogom progona kršćana.

Sveti Augustin na svoj način objašnjava tu silinu udarca po Kristovoj Crkvi: "Na stanovito i unaprijed određeno vrijeme, demonima je dana moć da u ljudi koje su zaposjeli pobuđuju silničku mržnju protiv Božjega grada, i ne samo što primaju žrtve od onih koji im ih prinose i zahtijevaju od onih koji su voljni, nego ih čak žestokim progonima iznuđuju od onih koji nisu voljni, što opet ne samo da nije pogibeljno po samu crkvu [sic!] nego je zapravo i korisno, jer se tima [sic!] ispunjava broj mučenika, (usp. Otk 6,11; usp. Tertulijan, Apologeticum, 50) koje, zatim, Božji grad smatra to slavnijim i časnijim građanima što se hrabrije bore protiv grijeha bezbožnosti, sve do prolijevanja vlastite krvi (Heb 12,4)."23

19 Euzebije Cezarejski, Crkvena povijest, 4,15,29. Citirano prema: Euzebije Cezarejski, Crkvena povijest, Služba Božja, Split, 2004.

20 Joseph Ratzinger, Zajedništvo u Crkvi, Verbum, Split, 2006., str. 117.

21 N. BIŽACA, nav. dj., str. 265.

22 A. Franzen, nav. dj., str. 43.

23 Aurelije Augustin, O Državi Božjoj, 10,21. Citirano prema: Aurelije AuGustin, O Državi Božjoj. De Civitate Dei, I.-III., Kršćanska sadašnjost, Zagreb, 1995. - 1996. 
Povjesničari progone kršćana uglavnom dijele na tri razdoblja. Prvo se razdoblje može ograničiti na prvo stoljeće. Progon je započeo car Neron (54. - 68.), koji je kršćane optužio da su u Rimu u srpnju 64. godine podmetnuli požar, a opće je mišljenje da je taj požar izazvao sam car. Čini se da se progon ograničio samo na glavni grad, a trajao je do Neronove smrti. U ovom progonu pogubljeni su apostolski prvaci Petar i Pavao. ${ }^{24}$ Jasno, pogibija apostolskoga prvaka Petra-Stijene i Apostola narodâ dobrano je uzdrmala prvotnu kršćansku zajednicu, ali kasnije se pokazalo da je njihova mučenička smrt urodila "stostrukim plodom".

U razdoblju nakon Nerona, za vrijeme vladanja Vespazijana i sina mu Tita, kršćani su ponovo živjeli u miru. Ali zadnjih godina pod Domicijanom (81. - 96.), kada je kult cara dosegao svoj vrhunac, jer se car zvao "gospodin i bog", što kršćani nikako nisu mogli prihvatiti, uslijedio je novi progon. Ovaj se progon ne može uspoređivati s onim iz Neronova vremena, ali ni on nije zanemariv, jer je odnio mnoge žrtve. ${ }^{25}$

Blagi car Nerva (96. - 98.) uspostavio je ponovo mir i za kršćane. On je zabranio bilo kakvu optužbu zbog toga što netko živi po židovskim pa i kršćanskim običajima. Ali poslije njega dolazi car Trajan (98. - 117.), vrlo sposoban vladar, koji je Rimsko Carstvo doveo do najvećega opsega. U njegovo su se vrijeme kršćani ponovo našli na udaru državne vlasti. ${ }^{26}$ Trajanov progon smatra se početkom drugoga razdoblja koje je trajalo do cara Decija (249. - 251.), kada počinje treće razdoblje. U svome pismu Pliniju Mlađemu Trajan piše da za kršćanima ne treba tragati i da se anonimne prijave ne smiju uzimati u obzir. Ipak, oni kršćani koji budu privedeni, ako ne zaniječu svoju vjeru zazivanjem rimskih bogova, trebaju biti kažnjeni. Dakle, ne traži se dokaz da je netko prekršio neki zakon, nego je dovoljno da se dokaže da je netko kršćanin i da bude kažnjen. Iz ovoga proizlazi da nije dopušteno biti kršćanin. ${ }^{27}$

Dva cara nakon Trajana bili su bolje raspoloženi prema kršćanima. Svojim reskriptima čak možemo reći da su štitili kršćane od narodnoga fanatizma, ali pravni položaj kršćana ostao je i dalje nepromi-

24 K. Bihlmeyer - H. Tuechle, nav. dj., str. 103-105; A. Franzen, nav. dj., str. 44-45.

25 K. Bihlmeyer - H. Tuechle, nav. dj., str. 105-106.

26 Isto, str. 106.

27 Hubert Jedin, Velika povijest Crkve, I., Kršćanska sadašnjost, Zagreb, 2001., str. 155. 
jenjen. Tako je car Hadrijan (117. - 138.) svojim reskriptom oko 128. godine čak zaprijetio onima koji prijavljuju kršćane iz koristi. Naredio je da svaka optužba protiv kršćana treba proći regularnu proceduru. Slično stajalište imao je i car Antonino Pio (138. - 161.), koji je u svom reskriptu zabranio da se kršćani optužuju zbog ateizma. Ipak, to ne znači da u to vrijeme kršćani nisu bili progonjeni. ${ }^{28}$

Sljedeći veliki progon bio je u vrijeme cara Marka Aurelija (161. 180.). U početku njegova vladanja zabilježene su teške nesreće: oskudica i kuga zavladale su u Carstvu, a k tomu barbari su ugrožavali njegove granice. Za ta zla ponovo su optuživani kršćani. Sam car u kršćanstvu nije vidio ništa drugo nego "duh proturječnosti" i "ludost zanesenjaštva". Kako su ti progoni bili okrutni, vidimo iz apologija Atenagore, Melitona, Apolinara i drugih, koji su svoja djela uputili samome caru. Doduše, u njegovo vrijeme nije izdat nikakav reskript protiv kršćana, ali onaj iz 176. godine kojim se osuđivalo na smrt one koji remete mir u društvu i uvode nove kultove, primjenjivan je i na kršćane. U Galiji su potvrđene odredbe koje su vrijedile u Trajanovo vrijeme. ${ }^{29} \mathrm{U}$ 2. stoljeću kršćani su samo u kraćim razdobljima bili pošteđeni progona. Iz toga stoljeća slavni su mučenici: Ignacije Antiohijski, apologet i filozof Justin i Polikarp iz Smirne.

U sljedećim desetljećima sve do sredine 3. stoljeća izmjenjivali su se razni carevi. Kršćani su u ovom razdoblju ponekad uživali relativan mir, s time da na lokalnoj razini progoni nikada nisu prestajali, a bilo je i progona širokih razmjera. Onda je na scenu stupio car Decije (249. - 251.), koji je htio obnoviti politiku velikoga stila. Želio je carstvu, koje je bilo na rubu rasula, vratiti nekadašnji sjaj, boreći se protiv vanjskih, ali i unutarnjih neprijatelja. $U$ tu svrhu mislio je svima, pa i kršćanima, koje je smatrao najvećim neprijateljima Rimskoga Carstva, nametnuti jedinstvenu staru pogansku vjeru. Iz ove odluke proizišao je sustavan progon koji je po svom značenju nadvisio sve prethodne. Posebno se okomio na biskupe i svećenike. Ovaj je car izjavio da bi lakše podnio svoga carskog suparnika negoli izbor novoga rimskog biskupa. Papinska stolica ostala je tada upražnjena više od godinu dana. ${ }^{30}$ I nakon Decija smjenjivala su se razdoblja mirnoga života i progona kršćana. U ovom razdoblju kršćani su, uz male prekide, imali 40-godišnji mir, koji je bio presudan za širenje Crkve.

28 K. Bihlmeyer - H. Tuechle, nav. dj., str. 107.

29 Isto, str. 108.

30 Isto, str. 113-114. 
U tom mirnom razdoblju od 260. godine kršćanstvo se raširilo gotovo po cijelome Carstvu. U gradovima su uspostavljene brojne $\mathrm{kr}$ šćanske zajednice. Mnogi kršćani zauzimali su važna mjesta u vojsci i na carskom dvoru. Ipak, ljudi iz raznih državnih struktura štitili su poganski kult. U vrijeme cara Dioklecijana (284. - 305.) dogodila se odlučujuća bitka između kršćanstva i Rimskoga Carstva. Ovaj je car u prvo vrijeme tolerirao kršćanstvo, čak su i njegova supruga i kći smatrane kršćankama, ali je onda 303. godine pokrenuo progon, krvaviji od svih dotadašnjih. Najprije je počelo čišćenje vojske. Svi oni koji nisu htjeli žrtvovati idolima, bili su izbačeni iz službe, a neki su bili ubijeni. ${ }^{31} \mathrm{U}$ roku od godine dana izašla su četiri edikta kojima se mislilo potpuno uništiti kršćanstvo. Bitka između ove dvije "univerzalne stvarnosti" završila je Konstantinovim preokretom i konačnom pobjedom kršćanstva. Milanskim ediktom 313. godine Crkva je ušla u novo povijesno razdoblje u kojemu je uživala mir, te joj je omogućen institucionalni razvitak. Zapravo, kršćanstvo je postalo državna religija. ${ }^{32}$

Pravna osnova kršćanskih progona, posebno onih prije Decija, nije potpuno jasna. Mnogi misle da su se protiv kršćana pokretali postupci na osnovi starih općih kaznenih zakona o nepriznatim skupinama, te na osnovi optužbe za magiju, ateizam, nepriznavanje cara itd. Drugi autori misle da su se već u prva vremena, u doba Domicijana, a možda i Nerona, izdavali posebni zakoni za progon kršćana. ${ }^{33}$ Ne možemo s potpunom sigurnošću govoriti o pravnim razlozima progona: je li izdan poseban zakon protiv kršćana, ili su se progoni temeljili na različitim zakonima koji su štitili kult poganskih bogova, ili se koristilo državno-policijsko pravo nadzora nad religio illicita (nedopuštenom religijom). ${ }^{34}$

O mučenicima prvih kršćanskih vremena sačuvani su razni spisi. Pravi zapisi o mučenicima zasnivaju se na službenim sudskim zapisnicima, ali i na neposrednom kazivanju očevidaca. Zatim imamo passiones ili martyria koje su sastavili vjerodostojni suvremenici, te na kraju legende i priče koje su nastale u kasnijim vremenima pa ih ne možemo smatrati vjerodostojnima. ${ }^{35}$

31 Isto, str. 117-118.

32 K. Bihlmeyer - H. Tuechle, nav. dj., str. 118-123; A. Franzen, nav. dj., str. 50.

33 K. Bihlmeyer - H. Tuechle, nav. dj., str. 100.

34 G. Grbešić, nav. dj., str. 22-23.

35 A. Franzen, nav. dj., str. 42-43. 


\section{Teologija mučeništva u ranom kršćanstvu}

Teologija mučeništva ima svoje korijene već u Svetome Pismu. Isus je u posebnom smislu mučenik Oca Nebeskoga, koji je kao utjelovljena Druga Božanska Osoba za spas čovjeka od njegova grijeha bez opiranja položio svoj život i kao takav je uzor svim mučenicima. On u žrtvi koja je završila na križu, na koju je dragovoljno pristao, daje najjače svjedočanstvo vjernosti svome Ocu. Isusova je muka vrhunac njegova poslanja, a njegovo je mučeništvo temelj na kojemu je Crkva sazdana, pa je i ona, kao Tijelo Kristovo, pozvana dati svjedočanstvo sve do prolijevanja krvi za spas čovječanstva. Već je i židovska zajednica u Starom Zavjetu imala svoje mučenike, osobito u doba Makabejaca (2 Mak 6-7), ali je mučeništvo u Novome Zavjetu dobilo potpuno nov smisao, pa ono za Kristove sljedbenike znači i bespogovorno nasljedovanje svoga Učitelja, te istinsko dioništvo u njegovu svjedočenju Radosne vijesti i u djelu spasenja. ${ }^{36}$ "Mučeništvo nije nekakva intelektualna spekulacija, ono je konkretnost života, štoviše, vrhunac jedne ljudske egzistencije, jer očituje puninu čovjekove slobode pred smrću." ${ }^{37}$ Uistinu, mučeništvo je vrhunac, ali i "izvor vjere". ${ }^{38}$

Već u prva kršćanska vremena ${ }^{39}$ pripadnici svih slojeva pristupali su Crkvi pa dosljedno tomu mučenicima su postajali ljudi raznovrsna imovnog stanja i društvenog položaja, počevši od robova i malih trgovaca i zanatlija, zatim srednjega društvenog sloja i vojnika pa sve do rimske vlastele. ${ }^{40}$

Isus je rekao da će njegove apostole progoniti i Židovi i pogani: "Čuvajte se ljudi, jer će vas predavati vijećima i po svojim će vas sinagogama bičevati. Pred upravitelje i kraljeve vodit će vas poradi mene, za svjedočanstvo njima i poganima" (Mt 10,17-18). Istinski učenik nije drukčiji od učitelja pa Isus svojim učenicima poručuje: "Sjećajte

36 "Mučenik", u: Rječnik biblijske teologije, (ur. XAVIER LeON-Dufour i dr.), Kršćanska sadašnjost, Zagreb, 1969., str. 600-602.

37 Rino Fisichella, "Martirio", u: René Latourelle - Rino Fisichella, Dizionario di Teologia Fondamentale, Cittadella editrice, Assisi, 1990., str. 681. Citirano prema: N. Dogan, nav. dj., str. 446.

38 J. Ratzinger, Zajedništvo u Crkvi, str. 119.

39 Iako pod pojmom prva kršćanska vremena uglavnom smatramo prva dva stoljeća, ipak se ovaj pojam može protegnuti i na razdoblje do Milanskoga edikta, pogotovo imajući u vidu područja koja su kristijanizirana tijekom 3. stoljeća.

40 A. ZRNo, "Društveni položaj mučenika za prvih kršć. vjekova", u: Obnovljeni život, vol. 13, br. 9, rujan 1932., str. 385-392. 
se riječi koju vam rekoh: 'Nije sluga veći od svoga gospodara.' Ako su mene progonili, i vas će progoniti" (Iv 15,20). Već pri opisu mučeništva sv. Polikarpa iz Smirne nalazimo misao da je mučeništvo istinsko nasljedovanje Krista u patnji i u smrti. ${ }^{41}$ Augustin kaže da su mučenici umrli za istinu i žive s Istinom. ${ }^{42}$ Po sebi kršćanstvo je nepolitična vjera. Ona ne traži političku moć, nego priznaje pravovaljanu državnu vlast (usp. Rim 13,1-7). Priznajući Isusa Krista Sinom Božjim, odnosno pravim Bogom, neizbježno se sudara s totalitarnim zahtjevom careve političke moći i u svakome će se vremenu sukobljavati s totalitarnim političkim režimima i dolaziti u situaciju mučeništva - u zajedništvo s raspetim Kristom koji vlada samo s "drveta". ${ }^{43}$

Ponekada i danas možemo čuti i vidjeti krivo poimanje čašćenja svetaca. Pojedinom svecu pripisuje se "božanska moć". Očito je toga bilo i u prvim kršćanskim vremenima pa je bilo uvijek iznova potrebno naglašavati da su svi ljudi obični smrtnici i da se njihova zagovornička moć temelji jedino u Trojednomu Bogu. Razlog čašćenja svetaca, a napose mučenika, nije u njima samima nego u još većem štovanju Boga. Crkva u mučenicima štuje Krista mučenika koji je ishodište njihove svetosti. ${ }^{44}$

Govoreći o čudesima koja se događaju po zagovoru mučenika, Augustin mučeništvo najizravnije povezuje s vjerom, jer je vjera ta životna snaga koja je krijepila mučenike u teškim trenutcima njihova stradanja: "O čemu drugome svjedoče ta čudesa ako ne o vjeri u kojoj se propovijeda da je Krist u puti uskrsnuo i sa puti na nebo uzašao? Jer i sami mučenici (martyres) bili su svjedoci (martyres) ${ }^{45}$ te vjere, to jest: svjedočili su o njoj; a pružajući svjedočanstvo o toj vjeri, pretrpjeli su ovaj najneprijateljskiji i najokrutniji svijet, i pobijedili su ga, ne borenjem, nego umiranjem. Za tu vjeru oni su umirali, i sada mogu steći sve ovo od Gospodina, zbog čijega su imena ubijeni. Radi te vjere oni su prvo pokazali čudesnu strepnju (patientia), da bi uslijedila golema moć tih čudesa." ${ }^{16}$

41 Usp. Johannes Quasten, Patrologia, I., Marietti, Torino, 1980., str. 77.

42 Aurelije Augustin, O Državi Božjoj, 4,30.

43 Joseph Ratzinger (Benedikt XVI.), Isus iz Nazareta, I., Verbum, Split, 2013., str. 344.

44 Elvis Ražov, "Ivan Pavao II. o mučeništvu", u: Obnovljeni život, Zagreb, 2/2014., str. 234.

45 Grč. riječ $\mu \alpha \dot{\alpha} \rho \tau v \varsigma$, korijenski znači "opominjač", a inače svjedok i mučenik. U tom je značenju preuzeta u latinski kršćanski govor.

46 Aurelije Augustin, O Državi Božjoj, 22,9. 
Augustin dalje nastavlja u apologetskom stilu objašnjavati razliku između mučenika i poganskih bogova, za koje su pogani tvrdili da i oni čine čudesa. "Mučenici nama nisu bogovi, jer mi poznajemo samo jednog Boga, koji je Bog i nama i mučenicima. Isto tako, čudesna djela što se događaju posredstvom moći naših mučenika nipošto se ne mogu usporediti s onim čudesima o kojima se govori kako su se zbila u njihovim [poganskim] hramovima. [...] I napokon, oni su takvim svojim bogovima izgradili hramove, podigli žrtvenike, uspostavili svećenike i prinosili žrtve. Mi pak mučenicima svojim ne gradimo hramove kao bogovima, nego spomen-svetišta, kao mrtvim ljudima, kojih duhovi žive kod Boga. Isto tako, tu ne podižemo žrtvenike na kojima žrtvujemo mučenicima, nego žrtvujemo na oltaru jednoga Boga, koji je zajednički i nama i mučenicima." ${ }^{17}$

Iako ponekad može izgledati da neki Kristov sljedbenik "fanatičnom željom za mučeništvom" zapravo izaziva svoju nasilnu smrt (kao što to neki misle u slučaju Ignacija Antiohijskoga ${ }^{48}$ i Origena), pristup ovom pitanju u kršćanstvu sasvim je drukčiji. Naime, Krist svojim učenicima poručuje: "Ne opirite se Zlomu! Naprotiv, pljusne li te tko po desnom obrazu, okreni mu i drugi. Onomu tko bi se htio s tobom parničiti da bi se domogao tvoje donje haljine prepusti i gornju. Ako te tko prisili jednu milju, pođi s njim dvije" (Mt 5,39-41). Euzebije Cezarejski o Origenu piše: "Požar progonstva uvelike je planuo. Veliki se broj ovjenčao vijencima mučeništva. Origen je bio još uvijek samo dijete. Ipak je njegovu dušu spopala tolika ljubav prema mučeništvu da je hrlio prema opasnostima. Poskakivao je i svom čežnjom srnuo u boj." ${ }^{49}$ Euzebije dalje nastavlja o Origenu: "Potpuno ga je prožela žudnja za mučeništvom." ${ }^{50} \mathrm{Kada}$ su uhitili Origenova oca, mladi ga je Origen savjetovao: "Pazi da radi nas ne promijeniš mišljenje."51

47 Isto, 22,10.

48 Ignacije je smatrao: "Ako nismo spremni za njega dragovoljno umrijeti njegovom smrću, ni njegov život nije u nama" (Magnežanima, V, 2). Citirano prema: Ruben IoAn Ivan, "Povezanost spasenja, mučeništva i trpljenja prema sv. Ignaciju Antiohijskom", u: Kairos, 2/2013., str. 196.

49 Euzebije Cezarejski, Crkvena povijest, 6,2,3.

50 Isto, 6,2,5.

51 Isto, 6,2,6. 
Crkva mučeništvo slavi kao izvanredno duhovno herojstvo, ${ }^{52}$ ali u tomu činu vidi i tragediju koja je zadesila dotičnoga čovjeka ili skupinu ljudi koji su ovozemaljski život dali za više ideale. Ta je tragedija ujedno i užasna i čudesna, "čudesna zbog nevinosti koja se poslušno predaje na mučenje bez pokušaja samoobrane". ${ }^{53} \mathrm{Tu}$ je čudesnu moć mučeništva kao misijske snage Crkve prvi iznio Tertulijan (Apologeticum, 21,50) u svojoj glasovitoj prispodobi o krvi kao sjemenu: "Plures efficimur quoties plures metimur a vobis; semen est sanguis christianorum" (Što nas više kosite, više rastemo; sjeme je krv kršćana). ${ }^{54}$ Taj izvanredni herojski čin mučenika i ispovjedalaca postaje "misijski činilac prvog reda koji privodi kršćanstvu istina ne brojne, ali vrlo kvalitetne skupine novih pristaša". ${ }^{55} \mathrm{O}$ misijskim plodovima prolivene mučeničke krvi govori i Augustin: "Unatoč strahotama i oporbi tolikih i tako golemih progona, ljudi su i najodanije uzvjerovali i neustrašivo propovijedali i s krvlju mučenika zasijavali prethodno Kristovo uskrsnuće i zatim ono svih ostalih u novome vijeku te besmrtnost puti, da urodi još većim plodom širom cijeloga svijeta." ${ }^{56}$

$\mathrm{U}$ jednom od svojih prvih djela, koje je relativno kratko (samo šest poglavlja), Ad martyres (Mučenicima) Tertulijan piše o nepokolebljivosti kršćana iz prvih vremena. One koji su dali svoj život za vjeru naziva blaženicima i mučenicima. "Umrijeti za Krista ne znači samo nezainteresirano podnijeti patnju i ostati stoički čvrst nego je to čin svjedočenja koji pretpostavlja hrabrost. To je borba u punom smislu riječi." ${ }^{57}$ Tertulijan dalje nastavlja da nije dovoljno samo nadvladati strah od mučeništva, nego prema njemu treba razviti pozitivan zanos. ${ }^{58}$ Augustin jasno kaže da mučenici snagom i borbom vjere svladavaju čak i strah od smrti. ${ }^{59}$ Znači, to je nadnaravni dar. U svome djelu Apologeticum Tertulijan ističe svoju žarku želju za mučeništvom, te ne prihvaća bijeg od progona, ${ }^{60}$ ali u djelu Ad uxorem $(1,3)$

52 Ipak, mučeništvo nije nekakvo čisto osobno junačko djelo, nego je ono milost moći trpjeti za Isusa. Joseph Ratzinger (BEnedikt XVI.), Isus iz Nazareta, II., Verbum, Split, 2011., str. 76.

53 E. RAžov, nav. dj., str. 240.

54 Usp. Aurelije Augustin, O Državi Božjoj, 22,7, bilj. 1.

55 H. JEDIN, nav. dj., str. 235.

56 Aurelije Augustin, O Državi Božjoj, 22,7.

57 Usp. J. QuAsten, nav. dj., str. 531.

58 Usp. Isto.

59 Aurelije Augustin, O Državi Božjoj, 13,4.

60 Usp. J. QuAsten, nav. dj., str. 494. 
ipak kaže da je bolje u vrijeme progona skloniti se iz jednoga mjesta u drugo nego ostati i zanijekati vjeru pri mučenju. ${ }^{61}$

Ciprijan, koji je i sam u vrijeme cara Valerijana 258. godine postao mučenikom, u svome traktatu De lapsis (O otpadnicima) izražava zadovoljstvo što je u proljeće 251. prestao progon kršćana i zahvaljuje Bogu na darovanomu miru, te hvali mučenike koji su svojom postojanošću dali dobar primjer ostaloj braći. Međutim, njegovu radost pomućuju oni koji su zbog progona otpali od vjere. Radi osobnih probitaka pali su i zanijekali vjeru. ${ }^{62}$

U svome razmišljanju o mučenicima (Exhortatio ad martyrium) Origen kaže da je kršćanin obvezan prihvatiti mučeništvo u zamjenu za tolika dobra koja smo primili od Boga. Mučenici znaju da Bog njihovom smrću i patnjom uzdiže njih same, a drugima pribavlja otkupljenje. ${ }^{63}$ Origen jasno kaže da je mučenik pravi Spasiteljev učenik. ${ }^{64}$ Augustin ističe da mučenik pobjeđuje zlo božanskim vrlinama. ${ }^{65}$ Origen smatra da se savršenstvo u Kristu ipak može postići i bez pravoga mučeništva: "Za one koji žele nasljedovati Krista, a ne mogu podnijeti pravo mučeništvo, preostaje duhovno mrtvljenje i odricanje. Mučenik i asketa imaju isti ideal - savršenstvo u Kristu." ${ }^{16} \mathrm{Za}$ razliku od svakoga drugog čina, mučeništvo je neopozivi pristanak uz Krista, jer sve što kršćanin učini dobroga, tijekom daljnjega života može pokvariti. Vidimo koliki su kroz povijest a i danas kršteni te su $\mathrm{u}$ životu postali indiferentni prema Kristovu evanđelju, a nerijetko su postali i neprijatelji Božji. Zato krštenje vodom ne jamči da će čovjek ostati uz ideal koji nudi krštenje, dok je mučeništvo definitivno opredjeljenje za Krista. Tertulijan u svome traktatu De baptismo kaže da krštenje vodom nije moguće ničim zamijeniti osim mučeništvom koje on naziva "drugo krštenje" ili "krštenje krvlju". ${ }^{67}$ Ciprijan, kao i Tertulijan, poznaje izvrsnije krštenje od krštenja vodom, a to je "krštenje krvlju" ili mučeništvo. ${ }^{68}$

61 Usp. Isto, str. 548.

62 Usp. Isto, str. 582.

63 Usp. Isto, str. 344.

64 Usp. Isto, str. 367.

65 Aurelije Augustin, O Državi Božjoj, 10,21.

66 Usp. J. Quasten, nav. dj., str. 367-368.

67 Usp. Isto, str. 521.

68 Usp. Isto, str. 608. 
Isto je tako i s konačnim spasenjem duše. Govoreći o mučeništvu, sveti su oci u više navrata naglašavali kako je najizvrsniji put do konačnoga cilja spasenja duše upravo mučeništvo. Sveti Justin, filozof i apologeta, u djelu Razgovor s Trifunom (prevedeno je i na hrvatski jezik - Zagreb, 2011.) kaže da duše pokojnika najprije idu u podzemlje i tu ostaju do kraja svijeta. Iznimka su mučenici. Njihove su duše odmah primljene u nebo. ${ }^{69}$ Slično Justinu i Tertulijan u svome djelu De anima kaže da sve duše ostaju u Hadu do uskrsnuća, osim mučenika koji odmah idu u nebo. ${ }^{70}$ Isto ponavlja i u djelu De resurrectione carnis gdje kaže da "nitko, napuštajući tijelo, izravno ne dobiva naslov stanovnika neba, a tu povlasticu imaju mučenici". ${ }^{71}$ Upravo su zato, još od Ciprijanova vremena, mjesni mučenici spominjani u liturgiji, zajedno s biblijskim svecima i ostalima. ${ }^{72}$

Na mnogo mjesta i u Starom i u Novom Zavjetu oholost je apostrofirana kao veliko zlo pa je i sveti Augustin osjetio potrebu protumačiti kako se pravi mučenik odnosi prema svojoj patnji: "Sveti se mučenici neće nipošto oholiti, kako [sic!] da učiniše štogod dostojno dioništva u onoj domovini gdje vlada vječna i istinska sretnost, ako su se borili sve do prolijevanja vlastite krvi, ljubeći pri tome ne samo svoju braću (za koju je proliše), nego i same neprijatelje, koji im je proliše, kao što im je naloženo, po vjeri u ljubav i ljubavlju za vjeru" [diligentes caritatis fide et fidei caritate]. ${ }^{73}$

$\mathrm{Na}$ kraju treba spomenuti da je sveti Ciprijan najzaslužniji što nam je sačuvan registar mučenika. Naime, ovaj je biskup Kartage, koji je i sam postao mučenikom, za života poticao sve crkvene zajednice da točno zabilježe datume kada je koji mučenik stradao kako bi se kršćanska zajednica na taj dan mogla okupiti na mučenikovu grobu i slaviti Euharistiju. ${ }^{74}$ Tako je ovaj kartaški biskup postao svojevrstan autor prvoga popisa mučenika.

69 Usp. Isto, str. 194.

70 Usp. Isto, str. 530.

71 Usp. Isto, str. 573.

72 Usp. Aurelije Augustin, O Državi Božjoj, 22,10, bilj. 2.

73 Aurelije Augustin, O Državi Božjoj, 5,18,2.

74 Marko Medved, Razmišljanja o kršćanskom mučeništvu iz crkveno-povijesnog vidika, http://www.miroslavbulesic.com/novosti/66-razmisljanje-okrscanskom-mucenistvu-iz-crkveno-povijesnog-vidika.html) (7. 6. 2016.). 


\section{Martyrdom as one of the characteristics of the first Christian times}

\section{Summary}

At the beginning of the article the author shortly speaks about social-religious circumstances in which Christ's Church was born, because it is necessary to put both the Church and its martyrs in the historical context. The article later on elaborates etymology of the term and meaning of the word martyrdom. Short overview of the governmental prosecution of the Church is given the next. The emphasis is put on the most severe prosecutions in order to illustrate the most important events from the first three centuries in which the Church was going through terrible pain and suffering, but it was also the time in which martyrs' blood became the seed for the new shoots of the Christ's Church. The fourth and the most important part of this article is theology of martyrdom in the early Christianity. Different opinions of the Christian fathers from the first centuries are given here. Some of these Church fathers also became martyrs.

Keywords: prosecution; martyr; baptism of blood; religion; salvation. 